\title{
Isis - recovery orientated Peer Mentor Program
}

\author{
Amanda Dearden*, Alison Lee \\ From 2013 ANZAED Conference: Inspiring Change: Person and Context \\ Melbourne, Australia. 23-24 August 2013
}

This initiative is the first of this kind in Australia and supports the development of a trained volunteer mentoring network, offering opportunities for people in early recovery to develop supportive mutually beneficial mentoring relationships through regular contact with someone who has lived through and recovered from body image or eating issues for a minimum six month mentoring contract.

Recovery Mentors at Isis- The Eating Issues Centre Inc. receive Peer Mentor Training that focusses on awareness of mentoring role, boundaries, skills, risk management and self- care, developing social networks and becoming a non-professional 'buddy'. Mentoring is provided as an additional support alongside the mentees current contact with professional medical and mental health support.

This poster will outline aims and components of the Isis Recovery Oriented Peer Mentor Program that has been trialled at Isis from late 2012 to present, and includes qualitative results and identified areas for further development. This project values lived experiences of recovery and seeks to build capacity to provide effective mentoring support, reflect on the mentoring journey and factors that contribute to recovery. Preliminary results show the program is effective in reducing social isolation, increases hope in the possibility of recovery and provides linkages back to community.

Published: 14 November 2013

doi:10.1186/2050-2974-1-S1-P5

Cite this article as: Dearden and Lee: Isis - recovery orientated Peer

Mentor Program. Journal of Eating Disorders 2013 1(Suppl 1):P5.

* Correspondence: amanda_dearden@isis.org.au
Isis - The Eating Issues Centre Inc, Australia

Submit your next manuscript to BioMed Central and take full advantage of:

- Convenient online submission

- Thorough peer review

- No space constraints or color figure charges

- Immediate publication on acceptance

- Inclusion in PubMed, CAS, Scopus and Google Scholar

- Research which is freely available for redistribution
( Bïomed Central 